\title{
Model of Growth of the Russian Corporations: Impaction of Institutional Factors
}

\author{
Elena Silova (Chelyabinsk State University, Russia) \\ Irina Belova (Chelyabinsk State University, Russia) \\ Daria Bents (Chelyabinsk State University, Russia)
}

\begin{abstract}
In modern conditions corporations are a core of economic system and many macroeconomic indicators depend on growth of corporations. Quality and intensity of growth of corporations depend on many factors, both internal, and external. Institutional factors, including efficiency of the contract relations, level of tax burden, quality of corporate institutes have huge impact on growth of corporations. The purpose of this work - to reveal factors of growth of the Russian corporations and to construct models of the Russian corporations' growth in a branch section. In research the assessment influence of tax loading on efficiency of the contract relations and growth of the Russian corporations is carried out. The analysis of growth of the Russian corporations in various branches (oil and gas, metallurgy, power industry) is carried out and models of their growth taking into account such factors, as tax burden, level of dividend payments and level of compensation of the administrative personnel are constructed. The degree of tax burden to efficiency improvement of contractual relations in Russian corporations was analyzed. The growth rate of sales revenue was taken as an indicator of the corporation efficiency. The factors influencing the growth rate of sales revenue were analyzed, the basis for the analysis was Cobb-Douglas production function with some clarifications.
\end{abstract}

\section{Introduction}

In modern conditions, corporations are a kernel of an economic system, and many macroeconomic indicators a standard of living and welfare of the population depend on the growth of corporations. In our opinion, today there is no integrated approach to the research of factors of the economic growth of corporations, in particular the question of the institutional factors influence of growth on economic growth remains insufficiently studied. In this work the efficiency of contact relations as an institutional factor of growth is investigated. In its turn this category is considered through a prism of the quality of corporate institutes, a level of opportunism and the qualification of managers. As an external institutional factor of the growth of corporations a level of a tax burden is considered. The paper's purpose is to construct models of factors of growth for Russian corporations.

Many factors influence the quality and intensity of the growth of corporations, both internal and external. Demand factors, factors of offer and factors defining the distribution of resources are considered as classical factors of economic growth.

We will understand a quantitative increase in the main indicators of activity as the economic growth of corporations (first of all outputs. although the number of personnel. fixed assets. etc. can be considered as indicators of growth), which is a basis for an increase of the efficiency of activity of corporation. Under "factors of economic growth" in this work we understand variables of the external and internal environment of a firm, which have a direct or indirect impact on economic growth. Scientists of different methodological directions tried to reveal the major factors of economic growth.

For the first time, factors of economic growth were considered by Jean-Baptiste say. He considered that three factors take part in the creation of a value of a product: work, land and capital. Say's law is an exclusively simple idea that the process of the production of goods creates an income which is exactly equal to the cost of goods made. It means that the production of any volume of products automatically ensures an income necessary for a purchase of all products in the market. An offer generates its own demand.

A. Marshall allocated such factors as: customs, the strength of family relations, public safety along with capital, that is to say, for the first time it is possible to speak about certain institutional factors of economic growth (Marshall, 1993).

J. M. Keynes puts forward the following "recipes" in "The General Theory" for the purpose ensuring an effective demand as a defining factor of growth and an increase of an employment rate (Keynes, 2012):

1. A monetary policy, the regulation of an interest rate. It was offered to lower a percent rate for credits, which will increase a gap between the cost of credits and the expected profitability capital investment and lift their "marginal efficiency". Businessmen will put money not in securities, but in production development.

2. A budgetary policy. In order to stimulate an effective demand, J. M. Keynes offered to increase public expenditures, state investments and government procurements of goods. It was also recommended to reduce taxes. But nevertheless J. M. Keynes considered the building-up of expenses as the main thing. 
Further on, an increase in the expenditure part of the state budget will be compensated by new tax revenues formed at the expense of an increase in the production and in the expansion of employment.

3. The redistribution of incomes in the interests of social groups gaining the lowest income. Such a policy was called on to increase "the demand" of these social groups, increase the monetary demand of mass buyers. A tendency for consumption in society is to increase.

4. A full-employment policy directed at prevention from a considerable unemployment, at an expansion of the system of social security.

E. Domar considered that investments are a factor of not only an income's creation, but also of new capacities. A dynamic balance of supply and demand according to E. Domar is defined by the dynamics of capital investments which form new capacities and a new income. Therefore, the task is reduced to determining the volume and the dynamics of investments.

R. Harrod developed the model E. Domar (Harrod, 2008). For various norms of growth, R. Harrod puts forward the following statement: the system of free business will effectively function if incomes grow at accelerated rates. Investments have to anticipate the dynamics of a consumer's demand.

R. Solow, E. Denison, J. Mid considered other agents as factors of economic growth. In particular, in Solow's model, a norm of savings is a key factor defining a level of stability of a capital-to-labour ratio (Solow, 1956). A higher norm of savings provides a bigger stock of capital and a higher level of production. Another factor of continuous economic growth in conditions of steady economy is population growth. A third source of economic growth, after investments and population increase is technical progress. In the neoclassical theory, technical progress means high-quality changes in production (an increase of the education of workers.an improvement of the organization of work, a growth of scales of production).

Schumpeter and Smith have different views. In Schumpeter's theory, population growth is exogenous, and a coefficient of savings is relatively constant and is not a locomotive of growth. Schumpeter did not attach a great value to distribution. From his point of view, alternating changes in the economic sphere were a locomotive of "development" (as a counterbalance to habitual growth). They were caused by different reasons (for example, a sudden opening-up of new sources of offer), but the main thing was an entrepreneurial innovation which provided for development (Schumpeter Y.. 1982).

T. Eggertsson, E. de Soto singled out cultural factors, legislation, fight for wealth distribution, a level of transactional expenses as agents of economic growth (Eggertsson, 2001; Soto, 2008).

In modern economic science, one distinguishes between straight and indirect factors by their way of impacting economic growth. Factors which make growth physically possible are considered as straight ones. This group includes factors of offer: the quantity and quality of natural resources, the quantity and quality of manpower, a volume of fixed capital, a level of the development of entrepreneurial abilities in society, technology and production organization. Indirect factors are conditions permitting to realize opportunities of economic growth, available with society.

\section{Methodology and Data}

It is possible to divide factors influencing the economic growth of large corporations, depending on a source of influence, into two groups: internal and external. Internal factors include: a position of a corporation in the market, available resources. their accessibility, quality, cost, a level of technological equipment, personnel potential, innovative activity and the motivation of personnel, the financial policy of a company, the level and quality of management, etc. In its turn, internal factors of growth can be divided into 3 groups: administrative, production and market. The classification of factors of the growth of corporations is presented in Table 1. Factors are classified by two main criteria: according to the extent of their influence on economic growth and depending on an impact source (Silova, 2007).

External factors of the economic growth of corporations are the reasons influencing them from outside directly (the appearance of alternative sources of resources and energy, market monopolization, the construction of new capacities. a loss of reputation of a company) and indirectly (a change of legislation in a country and the world.an increase in universal prices of resources. economic stability. a fall of an inflation rate, a change of the ratio between courses internal and foreign currencies). Indirect external factors of economic growth are distinguished as: market factors (a change of the world's prices of resources. a level of monopolization), financial and economic (a rate of inflation. an interest rate), normative legal factors, as well as factors connected with external economic regulation (export. other aspects of tariff and customs regulation), force majeure circumstances (natural disasters. military operations. a criminal situation).

Within the framework of a developed economic science, in our opinion, institutional factors of economic growth of corporations remain insufficiently investigated, which in this regard have a huge impact on the growth of corporations. Among them it is necessary to consider such institutional factors of economic growth, as efficiency of contract relations, a level of a tax burden, the quality of corporate institutes. In this work, an 
attempt is presented, aimed at revealing the influence of these factors on economic growth by the example of Russian corporations. We will consider at first in more detail the essence of these institutional factors and the mechanism of their influence on economic growth. Institutional factors reflect a level and the quality of development of the institutional environment of one or another state, one or another corporation. Institutional factors influence economic growth indirectly, defining a performance level of major production factors, setting a certain vector of social and economic development as a whole. For example, A. Marshall ascribes such a factor as "public safety" to agents of the growth of a country's gross revenue along with the number and productivity of workers, capital (saved-up wealth), natural resources and an equipment level. This factor can be treated as a generalized characteristic of a status of external and internal conditions of activity of economic entities.

\begin{tabular}{|c|c|c|}
\hline $\begin{array}{l}\text { Factors of Economic } \\
\text { Growth }\end{array}$ & Kind of Factor & Indices of Economic Growth \\
\hline Internal & Direct & \multirow{2}{*}{$\begin{array}{l}\text { - Number of concerned employees } \\
\text { - Skill level of personnel } \\
\text { - Labor productivity } \\
\text { - Quantity and structure of fixed assets of an } \\
\text { enterprise } \\
\text { - Investments in research and development }\end{array}$} \\
\hline \multirow[t]{2}{*}{ Factors of Offer } & $\begin{array}{l}\text { Quantity and quality of basic } \\
\text { factors of production }\end{array}$ & \\
\hline & Volume of productive capital & $\begin{array}{l}\text { Quantity and quality of capital } \\
\text { - Fixed property rights of an enterprise to certain } \\
\text { types of resources } \\
\text { - Volume of investments }\end{array}$ \\
\hline \multirow[t]{3}{*}{ Factors of Demand } & Indirect & \multirow[t]{2}{*}{ - Price of a corporation's products } \\
\hline & Price factors & \\
\hline & Non-price factors & $\begin{array}{l}\text { - Number of consumers of products } \\
\text { - Expectations of consumers } \\
\text { - Quality of production } \\
\text { - Demand stimulation }\end{array}$ \\
\hline \multirow[t]{2}{*}{ Factors of Distribution } & Involvement of resources & $\begin{array}{l}\text { - Volume of available stocks of resources } \\
\text { - Rights for the investigation and development of } \\
\text { new fields } \\
\text { - Level of the loading of a technological chain }\end{array}$ \\
\hline & $\begin{array}{l}\text { Rational distribution of } \\
\text { resources }\end{array}$ & $\begin{array}{l}\text { - Level of used technologies } \\
\text { - Production and processing monopolisation } \\
\text { - Improvement of mechanisms of committing } \\
\text { transactions in the market }\end{array}$ \\
\hline Institutional Factors & $\begin{array}{l}\text { Efficiency of internal } \\
\text { functioning }\end{array}$ & $\begin{array}{l}\text { - Efficiency of contractual relations } \\
\text { - Level and quality of management } \\
\text { - Motivation of personnel } \\
\text { - Culture of production } \\
\text { - Level of energy efficiency of resources } \\
\text { - Level of energy saving of resources } \\
\end{array}$ \\
\hline External Factors & Indirect & \multirow{2}{*}{$\begin{array}{l}\text { - Level of a tax burden } \\
\text { - Legislation and state policy } \\
\text { - Level of the development of the education } \\
\text { system and science } \\
\text { - System of values of society } \\
\text { - Culture level in society }\end{array}$} \\
\hline Institutional & $\begin{array}{l}\text { Efficiency of institutional } \\
\text { development }\end{array}$ & \\
\hline Factors of Demand & Non-price factors of demand & $\begin{array}{l}\text { - Price of associated goods and technologies } \\
\text { - Level of taxes and duties }\end{array}$ \\
\hline
\end{tabular}

Table 1. Classification of Factors and Indicators of Economic Growth of Corporations Source: authors

In Harrod-Domar's Keynesian model of economic growth, rates of it are defined by two variables: a share of investments (in this respect, a condition of equality of investments to savings is seldom satisfied in real life) and an efficiency of accumulation. In this regard, already on the basis of this model it is also possible to single out and major institutional factors of economic growth, having divided them into two main groups: one of them includes factors influencing a norm of the accumulation or a level of investments in a country (a tax system. a level of trust of citizens in the economic policy of the state. a rate of inflation. a monetary policy. etc.). We will attribute factors influencing efficiency of investments to the second group (a level of transactional expenses, the distribution and protection of property rights). We will also note that canonical scientists noted in their time that 
not only production factors themselves, but also their productivity which is assured by qualitative institutes, act as factors of economic growth.

By institutional factors we understand in this work the most general characteristics (conditions) of the institutional environment or separate institutes having the greatest impact on rates of economic growth in an indirect way by influencing the productivity of material factors of economic growth. Institutional factors define operating conditions of economic entities and determine the efficiency of their activity (Barkhatov de Pletnev, 2013).

One of the central institutional factors of growth, in our opinion, is the efficiency of contract relations in a corporation. It is known that corporations arose from the global process of the separation of property from management at the beginning of the twentieth century. The problem of similar separation and its consequence are considered in the institutional theory within the doctrine of "an agent-principal". Modern corporations are characterized by a plurality of entities of management and. respectively, by the existence of often diverging and even opposite interests, which can cause numerous conflicts. The main problem is already wider than the commonly accepted issues of relationships between managers and shareholders. And other groups of participants of corporate relations, including workers and the state, are more and more actively involved in processes of the distribution of resources and decision-making.

By the efficiency of contractual relations in a corporation we will understand an ability of the relations to satisfy economic interests of entities of contractual relations in a corporation on the basis of the redistribution of property rights. In its turn, by contractual relations in a corporation we will understand economic relations of an owner-manager, a manager-hired employee regarding the transfer of property rights on the basis of a developed system of institutes, for the purpose of harmonizing economic interests of entities.

Benz. (Bents, 2010) considers a defining level of the efficiency of contract relations as a major factor - a share of transferred property rights. The higher is a share of transferred ownership rights, the higher is a level of the efficiency of contract relations. In other words, the dependence between the considered values is positive.

The mechanism of the influence of managers' opportunism on the efficiency of contractual relations is quite clear: with an increase in managers' inclination to opportunism efficiency decreases. The opportunism of managers begins to manifest itself owing to differently directed interests, i.e. when their personal interests and those of owners cease to coincide. Shareholders are first of all interested in getting an income from the capital invested in a corporation, whereas managers are focused on personal enrichment. The existence of opportunism reduces a share of rights which it is expedient to transfer to a manager. A management's skill level, on the contrary, positively affects the efficiency of contractual relations. The lower is the skill level of a manager, the lower is a level of efficiency, which is provided by a unit of ownership transferred to a manager. A decrease of a skill level of a manager with a growth of opportunism similarly affects the level of the efficiency of contractual relations, reducing it.

According to E.S. Silova (Silova, 2007), corporate institutes have an important impact on the efficiency of contractual relations and are an important institutional factor, forming that institutional environment in which participants of corporate relations act. A corporate institute represents norms, rules, mechanisms and procedures which provide a balance of interests of all participants of corporate relations and a transparency of the management of a corporation. The most important functions of corporate institutes are decreasing an uncertainty and increasing stability of all corporate interactions, and lowering transactional expenses. Corporate institutes provide the creation and functioning of "the rules of the game" of all participants of corporate institutes. It depends on their quality, to what extent rights and interests all of operating entities are protected in a corporation, to what extent their interests are balanced, and to what extent major corporate procedures and legislation requirements are observed.

Among significant external institutional factors of economic growth, it is necessary to consider, in our opinion, a tax burden. A tax burden is one of concepts applied to an assessment of the influence of tax payments on the financial condition of a corporation, in particular, on an operating profit. According to I. A. Belova (Belova, 2011),tax payments play a significant role in the management of an operating profit of a corporation, stipulate the size of this profit, ways of achieving and increasing the welfare of owners of a corporation in the current and expected period. In this case, one of determinative goals of a corporation is the formation of an effective tax policy of an enterprise, permitting, on the one hand, to optimize inflows of tax payments and, on the other hand, to increase the overall effectiveness of operating activities of a corporation. An important role is played in this regard by an assessment of tax obligations, which permits to define the extent to which the existing tax system is burdensome for an economic entity and what share of resources is attracted by budget payments to themselves that is to determine a tax burden of a corporation.

The size of a tax burden depends on a multitude of factors, beginning from a kind of activity and a form of its implementation, a tax regime, an organizational and legal form of a corporation and features of tax and business accounting, fixed in an accounting policy. The calculation of a tax burden, as factor of economic growth, permits 
a corporation not only to carry out an analysis of its state for a number of years, but also to make a forecast of possible options of the changing of a tax burden, achieving its optimum value.

At the moment, Russian corporations have offered the following indicator with respect to an assessment of a tax burden, which enables one to obtain the most generalized characteristic of the efficiency of a chosen tax policy, namely a share of taxes in revenue. This indicator is defined as ratio of all taxes paid by an organization to revenue, including an income from other realizations. In this regard, this indicator may be used by corporations applying any system of taxation. However, it will strongly differ for corporations of various branches of economy. The highest level of a tax burden in the branches of national economy investigated by us falls on corporations of the oil and gas branch. A slightly lower level of a tax burden falls on corporations of the metallurgical branch. Corporations of the electrical power branch have the lowest level of a tax burden.

This research operates the financial reports made by 28 Russian corporations (of Oil and Gas, Metallurgical, Electric Power Branches). As a basis of research next indicators were used: revenue, sum of basic assets, expenditures on personnel, dividends to shareholders, sum of awards paid to key management personnel, tax burden. Growth Rate of indicators mentioned were used as parameters of the production functions. IAS financial reports from the official websites were taken as the information source.

We will accept a growth rate of revenue from sales as an indicator of the economic growth of a corporation. We will analyze factors influencing a growth rate of revenue from sales. Basing ourselves on othe neoclassical economic theory, a characteristic of which is the quantitative mathematical simulation of economic processes and phenomena, we will assume a production function as a basis of an analysis. By a production function a technological dependence between the quantity of the resources spent by a firm in a unit of time and the greatest possible volume of produced goods are understood.

A general view of the production function is as follows:

$$
Q=f\left(X_{1}, X_{2}, \ldots, X_{n}\right)
$$

where $Q$ is a release volume in a unit of time.

$\mathrm{X} 1 . \mathrm{X} 2 . \mathrm{Xn}$ is a quantity of used resources in a unit of time.

Among two-factorial production functions, that of Kobb-Douglas is the most known:

$Q=A \cdot X^{\alpha} \cdot Y^{\beta}$

Where $\mathrm{A}, \alpha, \beta$ are positive constants;

$\mathrm{X}, \mathrm{Y}$ is a quantity of employed resources (as a rule, labour and capital).

Let us take the function of Kobb-Douglas with some elaborations:

1) since indicators of the volume of production, labour and capital, have a cost assessment and are reflected in financial statements of corporations, then we will take an income from sales as a volume of production; expenses of a corporation on personnel as labour; and a cost of basic assets (understanding real capital by the notion of capital) as capital;

2) we will take a rate of the growth of a revenue from sales as a resultant indicator, and a growth rate of expenses on personnel and a growth rate of the residual cost of basic assets as factorial variables;

3) we will enter a production function as a third factor: in the first case a growth rate of incomes paid to shareholders following the results of a year; in the second case a growth rate of remunerations paid to key administrative personnel; in the third case a growth rate of a tax burden.

With the prerequisites stated above, a production function in the first case will be as follows:

$$
i_{Q}=A \cdot i_{K}^{\alpha} \cdot i_{L}^{\beta} \cdot i_{D}^{\gamma} \cdot i_{P}^{\lambda} \cdot i_{T}^{\varphi}
$$

Where $\mathrm{i}_{\mathrm{Q}}$ is an index of a change of a corporation's revenue (a ratio of the value of a revenue from the realisation of products in 2013 to the revenue of 2012);

$i_{K}{ }^{-}$is an index of a change of a corporation's capital (a ratio of the sum of basic assets in 2013 to the sum of basic assets in 2012);

$i_{L}-$ is an index of a change of labour (a ratio of expenditures on personnel in 2013 to the corresponding sum in 2012);

$i_{D}$ - is an index of a change of the value of incomes paid to shareholders (a ratio of the value of incomes of 2012 to the sum of incomes in 2011);

$i_{P}-$ is an index of a change of a sum of rewards paid to key management personnel of a corporation (a ratio of the value of the reward in 2013 to the sum of an award in 2012); 
$i_{T}{ }^{-}$is an index of a change of the value of the tax burden of a corporation in 2013 to the value of the tax burden in 2012);

$$
A, \alpha, \beta, \gamma-\text { are parameters of a function. }
$$

Therefore, along with classical factors of corporation growth - such as labor and capital - the contractual relationship efficiency, dividend policy and tax burden level were considered as institutional factors of corporation growth.

\section{Results}

We chose a number of large corporations with obviously various growth rates of incomes from sales as an object of our analysis. We will assume a list of top 400 corporations, published by the Rating Agency "Expert", as a basis, namely 9-10 corporations at a time from three key branches of Russian economy (Table 2).

Using selected financial data over the period 2012 - 2013 we calculated growth rate of the following indicators: revenue, sum of basic assets, expenditures on personnel, dividends to shareholders, sum of rewards paid to key management personnel, tax burden. Therefore, according to received results we have come to the following conclusions:

- the most stable growth of basic assets are given by Oil and Gas Branch;

- as for the indicator "expenditures on personnel" we can see different tendencies in researched Branches: for example, Rosneft and Novatek show considerable increase of the indicator; other Corporations show decrease of the indicator; the highest growth rate are presented by Oil and Gas Branch; inessential growth rate are given by Metallurgical and Electric Power Branches;

- the indicator "dividends" has the greatest volatility; for example, MMP and AVISMA show multiple increase of the indicator; other Companies show decrease of the indicator (for example, Lenenergo and NLMP);

- the indicator "rewards paid to key management personnel" increase at a low pace; Holding MRSK and Norilskynickel are exclusions - these Companies show decrease the indicator;

- the indicator "tax burden" has no clear tendency.

For the next step we use the following results (Table 2) for building the production functions.

Then we took correlation analysis between the indicators mentioned above. According to received results we have come to the following conclusions:

- the strongest connection is seen between Growth Rate of Revenue and Growth Rate of Expenditures on Personnel;

- less strong connection is seen between Growth Rate of Revenue and Growth Rate of Capital, as well as between Growth Rate of Revenue and Growth Rate of Rewards to key management Personnel;

- connection between Growth Rate of Revenue and other indicators almost is insufficient (line correlation coefficient between Growth Rate of Revenue and Growth Rate of Dividends is only 0,065; line correlation coefficient between Growth Rate of Revenue and Growth Rate of Tax Burden is at the lowest level 0,012). 


\begin{tabular}{|c|c|c|c|c|c|c|c|}
\hline $\begin{array}{l}\text { Serial } \\
\text { Number }\end{array}$ & Corporation & $\begin{array}{c}\text { Growth } \\
\text { Rate of } \\
\text { Revenue }\end{array}$ & $\begin{array}{l}\text { Growth } \\
\text { Rate of } \\
\text { Capital }\end{array}$ & $\begin{array}{l}\text { Growth Rate of } \\
\text { Expenditures on } \\
\text { Personnel }\end{array}$ & $\begin{array}{c}\text { Growth } \\
\text { Rate of } \\
\text { Dividends }\end{array}$ & $\begin{array}{l}\text { Growth } \\
\text { Rate of } \\
\text { Rewards }\end{array}$ & $\begin{array}{c}\text { Growth } \\
\text { Rate of Tax } \\
\text { Burden }\end{array}$ \\
\hline \multicolumn{8}{|c|}{ Corporations of Oil and Gas Branch } \\
\hline 1 & JSC "Lukoil”" & 1.02 & 1.17 & 1.00 & 0.83 & 1.13 & 0.98 \\
\hline 2 & JSC “Gasprom” & 0.97 & 1.02 & 0.95 & 0.86 & 1.08 & 0.93 \\
\hline 3 & JSC “Tatneft” & 0.96 & 0.98 & 1.01 & 1.13 & 1.00 & 1.03 \\
\hline 4 & JSCNK “Rosneft" & 1.41 & 1.88 & 1.31 & 1.11 & 1.00 & 0.98 \\
\hline 5 & $\begin{array}{l}\text { JSC NGK } \\
\text { "Slavneft" }\end{array}$ & 0.90 & 1.00 & 0.96 & 0.73 & 0.92 & 0.99 \\
\hline 6 & JSC "Novatek" & 1.31 & 1.15 & 0.94 & 1.04 & 1.13 & 1.03 \\
\hline 7 & $\begin{array}{l}\text { JSC } \\
\text { "Surgutneftegas" }\end{array}$ & 0.84 & 1.64 & 1.02 & 1.14 & 0.95 & 1.16 \\
\hline 8 & JSC NK "Russneft" & 0.84 & 1.32 & 1.02 & 1.02 & 1.02 & 0.91 \\
\hline 9 & $\begin{array}{l}\text { Alliance Oil } \\
\text { Company }\end{array}$ & 1.09 & 1.01 & 1.03 & 1.00 & 1.29 & 0.91 \\
\hline \multicolumn{8}{|c|}{ Corporations of Metallurgical Branch } \\
\hline 10 & JSC "EvrazGroup" & 0.90 & 0.94 & 1.07 & 0.76 & 1.52 & 0.68 \\
\hline 11 & JSC "Severstal" & 0.89 & 1.13 & 1.10 & 0.78 & 1.08 & 0.77 \\
\hline 12 & JSC “RUSAL” & 0.89 & 0.95 & 1.06 & 1.00 & 1.21 & 0.32 \\
\hline 13 & $\begin{array}{l}\text { JSC } \\
\text { "Magnitogorsky } \\
\text { Steel-Making } \\
\text { Integrated Plant" } \\
\text { (MMP) }\end{array}$ & 1.00 & 1.00 & 1.09 & 20.60 & 0.95 & 1.04 \\
\hline 14 & $\begin{array}{l}\text { JSC "Novolipetsky } \\
\text { Steel-Making } \\
\text { Integrated Plant" } \\
\text { (NLMP) }\end{array}$ & 1.04 & 1.11 & 0.49 & 0.23 & 0.98 & 0.73 \\
\hline 15 & JSC "Mechel" & 0.90 & 1.11 & 1.29 & 0.89 & 5.20 & 1.26 \\
\hline 16 & $\begin{array}{l}\text { JSC } \\
\text { "Norilskynickel" }\end{array}$ & 1.02 & 1.03 & 1.05 & 0.79 & 0.09 & 0.89 \\
\hline 17 & JSC “ChTPZ” & 0.85 & 0.55 & 1.08 & 1.00 & 1.00 & 1.45 \\
\hline 18 & $\begin{array}{l}\text { JSC "Corporation } \\
\text { VSMPO- } \\
\text { AVISMA" }\end{array}$ & 1.20 & 1.16 & 1.12 & 5.13 & 1.00 & 1.22 \\
\hline 19 & $\begin{array}{l}\text { JSC "Chelyabinsk } \\
\text { Zinc Plant" }\end{array}$ & 1.03 & 0.29 & 1.00 & 1.00 & 1.00 & 0.69 \\
\hline \multicolumn{8}{|c|}{ Corporations of Electric Power Branch } \\
\hline 20 & Holding MRSK & 0.98 & 1.11 & 0.97 & 0.88 & 0.04 & 0.77 \\
\hline 21 & JSC "EnelOGK-5” & 1.10 & 1.08 & 1.15 & 1.00 & 1.61 & 1.73 \\
\hline 22 & JSCFSKEES & 1.01 & 1.12 & 1.09 & 0.01 & 0.64 & 0.16 \\
\hline 23 & $\begin{array}{l}\text { JSC “Inter RAO } \\
\text { EES” }\end{array}$ & 1.04 & 1.24 & 1.20 & 1.02 & 1.69 & 0.61 \\
\hline 24 & $\begin{array}{l}\text { JSC "Far East } \\
\text { Power-Generating } \\
\text { Company" }\end{array}$ & 1.05 & 1.11 & 1.00 & 1.00 & 1.02 & 1.00 \\
\hline 25 & JSC "Lenenergo" & 1.03 & 1.05 & 1.01 & 0.37 & 0.84 & 0.98 \\
\hline 26 & $\begin{array}{l}\text { JSC “Kvadra- } \\
\text { Power-Generating } \\
\text { Company } \\
\text { компания» }\end{array}$ & 0.99 & 1.28 & 1.10 & 0.63 & 1.80 & 1.00 \\
\hline 27 & JSC “ Rusgidro" & 0.81 & 1.06 & 0.98 & 0.99 & 0.96 & 0.55 \\
\hline 28 & $\begin{array}{l}\text { JSC Concern } \\
\text { "Rosenrgoatom" }\end{array}$ & 0.99 & 1.14 & 1.08 & 1.00 & 1.13 & 2.12 \\
\hline
\end{tabular}

Table 2. Result of Calculation of Factors of the Production Function Source: the above is calculated by the authors on the basis of data of corporations' financial statements

The interconnection between indicators researched in Oil and Gas Branch is demonstrated on Figures 1, 2, 3. 


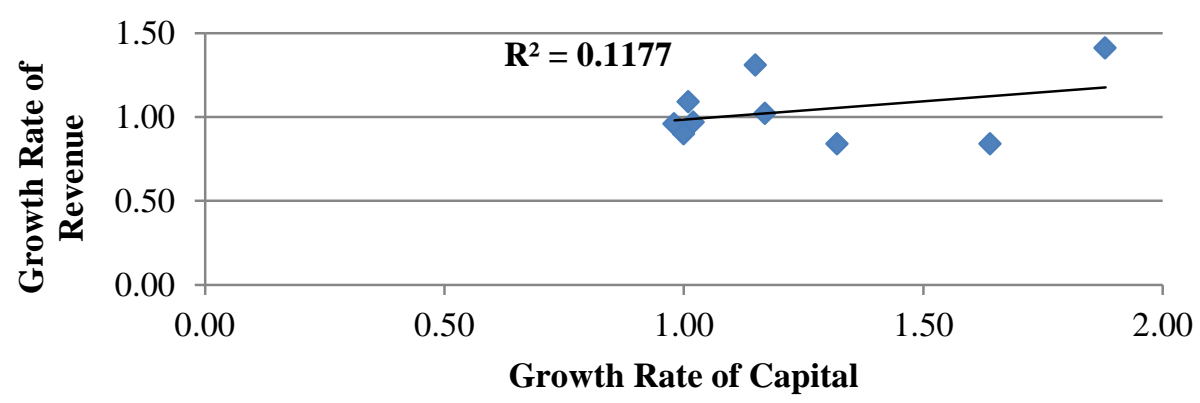

Figure 1. The correlation between Growth Rate of Revenue and Growth Rate of Capital in Oil and Gas Branch

The line correlation coefficient (r) between Growth Rate of Revenue and Growth Rate of Capital is only 0,118. That's why we can state insufficient connection of these indicators.

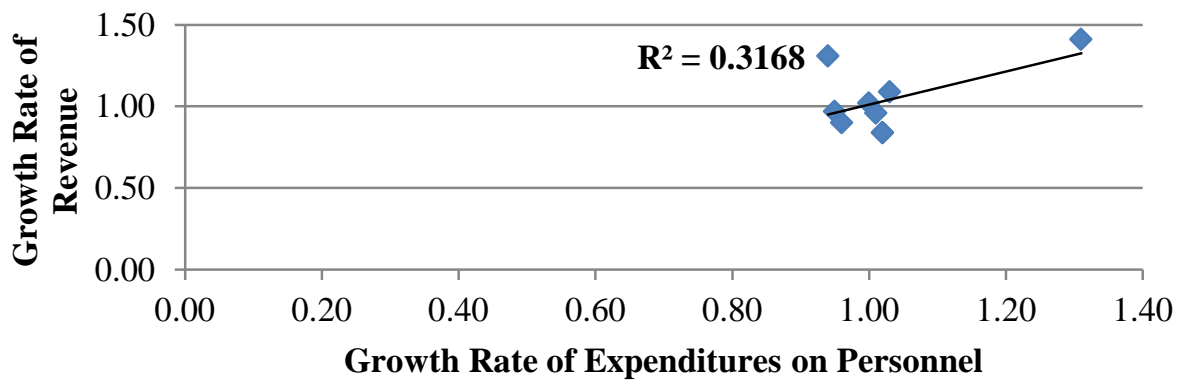

Figure 2. The correlation between Growth Rate of Revenue and Growth Rate of Expenditures on Personnel in Oil and Gas Branch

The line correlation coefficient (r) between Growth Rate of Revenue and Growth Rate of Expenditures on Personnel is 0,317 . Therefore we can state stronger connection of these indicators.

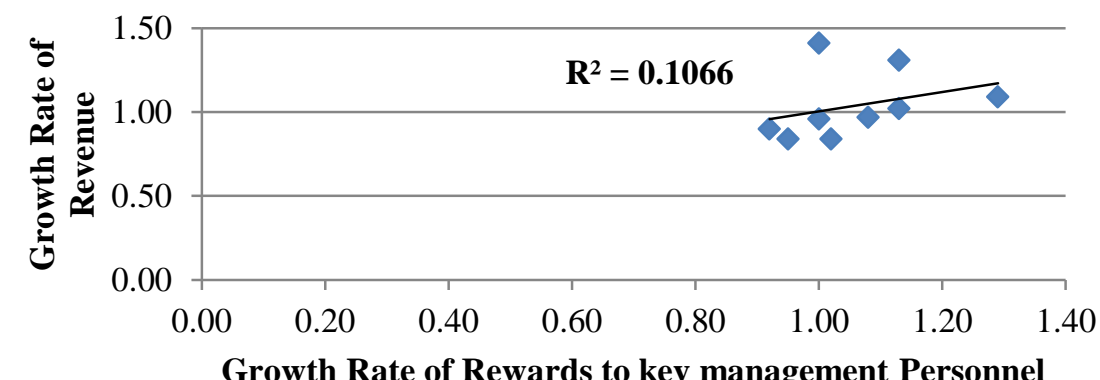

Figure 3. The correlation between Growth Rate of Revenue and Growth Rate of Rewards to key management Personnel in Oil and Gas Branch

The line correlation coefficient ( $r$ ) between Growth Rate of Revenue and Growth Rate of Rewards to key management Personnel is 0,107 . This connection is insufficient.

The correlation between indicators researched in Metallurgical and Electric Power Branches is the same or even less sufficient.

A calculation of parameters of production functions for Russian corporations specified in Table 2 led to the following results: 


\begin{tabular}{|c|l|c|c|}
\hline $\begin{array}{l}\text { Serial } \\
\text { Number }\end{array}$ & \multicolumn{1}{|c|}{ Branch } & \multicolumn{1}{|c|}{ Production function } & $\begin{array}{c}\text { Determination ratio } \\
\left(\mathrm{R}^{2}\right)\end{array}$ \\
\hline 1 & $\begin{array}{l}\text { Oil and Gas Branch of } \\
\text { Russia }\end{array}$ & \multicolumn{1}{|c|}{$i_{Q}=0,97 \cdot i_{K}^{0,16} \cdot i_{L}^{1,53} \cdot i_{D}^{-0,18} \cdot i_{P}^{-0,13} \cdot i_{T}^{0,088}$} & 0.52 \\
\hline 2 & $\begin{array}{l}\text { Metallurgical Branch of } \\
\text { Russia }\end{array}$ & $i_{Q}=0,96 \cdot i_{K}^{0,0005} \cdot i_{L}^{0,206} \cdot i_{D}^{0,046} \cdot i_{P}^{-0,03} \cdot i_{T}^{0,038}$ & 0.51 \\
\hline 3 & $\begin{array}{l}\text { Electric Power Branch of } \\
\text { Russia }\end{array}$ & $i_{Q}=0,94 \cdot i_{K}^{0,06} \cdot i_{L}^{0,77} \cdot i_{D}^{-0,036} \cdot i_{P}^{-0,003} \cdot i_{T}^{0,09}$ & 0.54 \\
\hline
\end{tabular}

Table 3. Results of the Construction of Production Functions Source: it is calculated by authors on the basis of the corporations given to financial statements

The coefficient of multiple determination of $\mathrm{R}^{2}$ of the constructed regression made 0.51-0.54 that speaks about acceptable level of adequacy of the constructed model. To top management and an index of dividends in all three functions I made degree of an index of the amount of remunerations either insignificant size, or negative that speaks about inverse relationship between the size of proceeds from sales of production and the amount of the paid remunerations. Thus, construction of production functions allows to draw a conclusion that payments and to shareholders, and managers do not depend on what speed the corporation develops and grows.

In addition to the received results, we will carry out a correlation analysis the results of which are reflected in Table 4.

\begin{tabular}{|c|c|c|c|}
\hline Factors & $\begin{array}{c}\text { Revenue Index of } \\
\text { Corporations of a } \\
\text { Metallurgical } \\
\text { Complex }\end{array}$ & $\begin{array}{c}\text { Revenue Index of } \\
\text { Corporations of an Oil } \\
\text { and Gas Complex }\end{array}$ & $\begin{array}{c}\text { Revenue Index of } \\
\text { Corporations of a } \\
\text { Power Complex }\end{array}$ \\
\hline Index of Capital & 0.18 & 0.34 & 0.16 \\
\hline $\begin{array}{c}\text { Index of Expenditures on } \\
\text { Personnel }\end{array}$ & 0.25 & 0.58 & 0.52 \\
\hline Index of Dividends & 0.26 & 0.25 & 0.09 \\
\hline $\begin{array}{c}\text { Index of Rewards to key } \\
\text { management Personnel }\end{array}$ & -0.32 & 0.34 & 0.33 \\
\hline Index of a Tax Burden & 0.12 & -0.14 & 0.27 \\
\hline
\end{tabular}

Table 4. Results of the correlation analysis

The results of the correlation analysis permit to draw the following conclusions: the most essential factor of the growth of corporations is man. It is work and labour productivity that can be referred to a key factor, which fact is confirmed by the classical economic theory. Institutional factors have very weak influence on economic growth of corporations as well as contractual relationship efficiency. Moreover, the connection between Growth Rate of Revenue and Growth Rate of Rewards to key management Personnel in Metallurgical Complex is negative. That's why influence of managers' qualification on Corporation Growth Rate is quite doubtful. Tax burden also doesn't have effect on corporation growth (all researched sectors show low correlation coefficient).

We considered dividend policy as a significant institutional factor. The theory says dividends are good indicator for the investment market. High dividends make corporation more attractive for investors, favoring corporation value growth and the improvement of company's goodwill. However, according to numbers this factor is also insufficient for Russian corporations.

\section{Conclusions}

As a result of the obtained calculations, we can draw the following conclusions: capital and labour being classical factors of the growth of corporations do not equally manifest themselves in various branches of Russian economy. The strongest impact is made by the growth of capital in an oil and gas complex. Such an influence of capital in a power branch can be explained by a fact that it is the oil and gas complex of Russia that is the most capital-intensive: the constant need of the world in fuel resources demands for essential investments into the modernization of basic capital.

The growth of incomes makes an extremely insignificant impact on a corporation's growth. The same concerns remunerations as well. Remunerations of managers of large Russian corporations are so great that any further growth of will practically not have any positive impact on the growth of corporations. As a result, remunerations can be in no way attributed to factors of the growth of Russian corporations. 
Regarding a tax burden, it is possible to state the following: tax legislation of Russia is extremely loyal with respect to large corporations which were exactly an object of our research. And therefore, small rates of the growth or decrease of a tax burden will not have any impact on a corporation's growth. In our opinion, such a factor as a tax burden will make an impact only in case of big fluctuations.

Thus, each of the considered factors separately makes an insignificant impact on a corporation's growth. In our opinion, it is a level of efficiency of contractual relations that is a key factor of the growth and development of Russian corporations. Today, contractual relations in the majority of corporations are not regulated and therefore not all Russian corporations show an essential growth.

\section{References}

- $\quad$ Eggertson, 2001. Economic behavior and institutions. Delo: Moscow

- Harrod, 2008. An Essay in Dynamic Theory/edited by Grebennikova, V., Central economics and mathematics institute RAS: Moscow

- Keynes, (2012). General theory of employment interest and money / edited by prof.Lubimova. Gelios: Moscow.

- Marshall, 1993. Principles of economics. Vol. 1. Progress: Moscow.

- Shumpeter, 1982. Theory of economic development. Progress: Moscow

- Silova, 2007. Quality of the institutional environment and its effect on economic growth. The dissertation on competition degree of candidate of economic sciences. Chelyabinsk.

- Soto, 2008. Another way. Moscow

- Barhatov, Pletnev, (2013). «Corporate governance in Russia: approaches, problems and solutions». Economy in the context of globalization: challenges, trends, prospects, pp. 25-31.

- Belova, (2011). «Estimation of efficiency tax policy in the Russian corporations». BulletinofChelyabinskStateUniversity. Series «Economy»,Vol. 32(247), pp. 108-113;

- Bents, (2010). «Effectiveness of contractual relations in the corporation». Bulletin of Chelyabinsk State University. Series «Economy», Vol. 28(209), p. 91.

- Solow, 1956. «A Contribution to the Theory of Economic Growth”. Quarterly Journal of Economics, Vol. 70, p. 65-94. 